\title{
PENGARUH BERBAGAI TINGKAT FRAKSI EKSTRAK DAUN SIRIH (Piper betle L.) dan DAUN BABADOTAN (Ageratum conyzoide) TERHADAP Colletotrichum capsici PENYEBAB PENYAKIT ANTRAKNOSA PADA CABAI (Capsicum annum L.) SECARA IN VITRO
}

\author{
Intan Rahayu Ningtyas, Efri \& Titik Nur Aeny \\ Jurusan Agroteknologi, Fakultas Pertanian Universitas Lampung \\ Jl. Prof. Soemantri Brodjonegoro, No. 1, Bandar Lampung 35145 \\ E-mail: intan_rahayuningtyas@yahoo.com
}

\begin{abstract}
ABSTRAK
Salah satu kendala untuk meningkatkan produktivitas cabai, baik dari segi kualitas maupun kuantitas adalah penyakit antraknosa, yang disebabkan oleh jamur Colletotrichum capsici. Penelitian ini bertujuan untuk mengetahui pengaruh berbagai tingkat fraksi ekstrak daun sirih (Piper betle L.) dan daun babadotan (Ageratum conyzoides) terhadap pertumbuhan C. capsici secara in vitro. Percobaan terdiri dari dua sub percobaan, masing-masing sub percobaan disusun dalam rancangan acak lengkap (RAL) dengan sebelas perlakuan dan tiga ulangan. Perlakuan sub percobaan pertama terdiri dari kontrol (PDA tanpa perlakuan ekstrak daun sirih), ekstrak daun sirih dengan pelarut aquades, ekstrak daun sirih dengan pelarut alkohol 10\% (daun sirih + alkohol 10\%), pelarut alkohol 50\% (daun sirih + alkohol 50\%), pelarut alkohol 90\% (daun sirih + alkohol 90\%), pelarut etil asetat $10 \%$ (daun sirih + etil asetat 10\%), pelarut etil asetat 50\% (daun sirih + etil asetat 50\%), pelarut etil asetat $90 \%$ (daun sirih + etil asetat $90 \%$ ), pelarut $n$-heksana $10 \%$ (daun sirih $+n$-heksana $10 \%$ ), pelarut $n$-heksana $50 \%$ (daun sirih $+n$-heksana $50 \%$ ), dan pelarut n-heksana 90\% (daun sirih $+\mathrm{n}$-heksana 90\%). Sub percobaan kedua adalah ekstrak daun babadotan dengan perlakuan yang sama dengan ekstrak daun sirih. Data hasil pengamatan dianalisis menggunakan sidik ragam dan perbedaan nilai tengah antar perlakuan diuji dengan Uji Jarak Berganda (Duncan) pada taraf nyata 5\%. Hasil penelitian menunjukkan bahwa perlakuan ekstrak daun sirih pada fraksi ekstrak n-heksana 50\%, n-heksana 90\%, n-heksana 10\% dan etil asetat 90\% menunjukkan pengaruh penghambatan terhadap pertumbuhan C. capsici. Pada daun sirih, fraksi ekstrak n-heksana 50\%, n-heksana 90\%, nheksana $10 \%$ dan etil asetat 90 dapat berpengaruh dalam menghambat pertumbuhan jumlah spora. Pada ekstrak daun babadotan, fraksi ekstrak n-heksana 10\%, n-heksana 50\%, n-heksana 90\% dapat menghambat pertumbuhan C. capsici. Tetapi, pada jumlah spora daun babadotan, tidak berpengaruh terhadap pertumbuhan spora.
\end{abstract}

kata kunci : Penyakit antraknosa (Colletotrichum capsici), daun sirih, daun babadotan.

\section{PENDAHULUAN}

Antraknosa adalah penyakit yang sangat menakutkan bagi pekebun cabai. Daya rusak penyakit ini sangat tinggi dan penularanya juga sangat cepat sehingga sangat merugikan petani atau pengusaha agribisnis apabila tidak dikenali dan dikendalikan dengan tepat dan cepat. Menurut Semangun (2000), penyakit antraknosa dapat terjadi pada daun, batang, dan buah cabai. Gejala antraknosa yang timbul pada buah berupa bercak-bercak putih, warna kehitaman dan membusuk kemudian rontok. Sedangkan pada biji dapat menimbulkan kegagalan berkecambah atau bila telah menjadi kecambah dapat menimbulkan rebah kecambah. Pada tanaman dewasa dapat menimbulkan mati pucuk, infeksi lanjut ke bagian lebih bawah yaitu daun dan batang yang menimbulkan busuk kering warna cokelat kehitam-hitaman (Nazaruddin, 1999).

Aplikasi fungisida sintentik merupakan cara umum dan paling populer digunakan oleh petani untuk mengendalikan penyakit antraknosa pada cabai. Akan tetapis cara ini berdampak negatif bagi lingkungan, dan manusia yang mengkonsumsinya. Oleh sebab itu, perlu dicari alternatif pengendalian penyakit antraknosa yang tidak menimbulkan dampak negatif, misalnya dengan penggunaan fungisida nabati.

Menurut Octriana dan Noflindawati (2010), fungisida nabati dapat dihasilkan dari tanaman-tanaman yang mengandung asam-asaman, minyak atsiri, senyawa fenol, ester, asam amino, gula sederhana, alkaloid dan ion organik, karena kandungan tersebut mampu mempengaruhi pertumbuhan dan perkembang biakan jamur. Hasil penelitian Guenther (1989) menunjukkan bahwa minyak atsiri mampu menghambat pertumbuhan sel vegetatif dan pertumbuhan spora dari beberapa golongan jamur seperti $C$. cereus, $C$. subtilis, dan $C$. magaterium.

Sirih (P. betle L.) dan babadotan (A. conyzoides) dilaporkan memilik memiliki kandungan minyak atsiri berpeluang sebagai bahan baku fungisida nabati yang 
murah dan mudah diperoleh (Marjannah, 2004). Penelitian ini bertujuan untuk mengetahui pengaruh berbagai tingkat fraksi ekstrak daun sirih (P. betle L.) dan daun babadotan (A. conyzoides) terhadap pertumbuhan C.capsici secara in vitro.

\section{BAHAN DAN METODE}

Percobaan terdiri dari dua sub percobaan, masingmasing sub percobaan disusun dengan rancangan acak lengkap (RAL) dengan sebelas perlakuan dan tiga ulangan. Sub percobaan pertama dengan perlakuan terdiri dari kontrol (PDA tanpa perlakuan ekstrak daun sirih), ekstrak daun sirih dengan pelarut aquades, ekstrak daun sirih dengan pelarut alkohol 10\% (daun sirih + alkohol 10\%), pelarut alkohol 50\% (daun sirih + alkohol $50 \%$ ), pelarut alkohol 90\% (daun sirih + alkohol 90\%), pelarut etil asetat $10 \%$ (daun sirih + etil asetat 10\%), pelarut etil asetat $50 \%$ (daun sirih + etil asetat 50\%), pelarut etil asetat $90 \%$ (daun sirih + etil asetat 90\%), pelarut n-heksana 10\% (daun sirih + n-heksana 10\%), pelarut n-heksana 50\% (daun sirih + n-heksana 50\%), dan pelarut $n$-heksana $90 \%$ (daun sirih + n-heksana 90\%). Sub percobaan kedua adalah ekstrak daun babadotan dengan perlakuan yang sama dengan ekstrak daun sirih. Data hasil pengamatan dianalisis menggunakan sidik ragam dan perbedaan nilai tengah antar perlakuan diuji dengan Uji Jarak Berganda (Duncan) pada taraf nyata $5 \%$.

Penyiapan Isolat Colletotrichum capsici. Jamur C. capsici diisolasi dari buah cabai yang menunjukkan gejala busuk atau terinfeksi. Jaringan kulit buah yang bergejala dipotong pada bagian perbatasan antara bagian yang sakit dan yang sehat $( \pm 5 \mathrm{~mm})$, kemudian potongan direndam dalam larutan alkohol dan dibilas dengan aquades steril. Selanjutnya potongan kulit buah tersebut ditanam dalam cawan petri yang berisi media PDA dan inkubasi dalam suhu ruang selama 3 hari. Jamur yang tumbuh kemudian isolasi dan diidentifikasi.

Penyiapan Fraksi Ekstrak Daun Sirih dan Daun Babadotan. Daun sirih dan daun babadotan diperoleh di sekitar lingkungan Raja Basa, Bandar Lampung. Daun sirih sebanyak $100 \mathrm{~g}$ dicuci dengan air bersih dan dikeringanginkan lalu dipotong-potong dan diblender untuk memperoleh bentuk yang lebih halus. Selanjutnya daun yang telah halus dilarutkan menggunakan alat yang dirancang menggunakan paralon. Penyaringan dilakukan secara bertingkat dengan dilarutkan ekstrak daun sirih dengan pelarut aquades, ekstrak daun sirih dengan pelarut alkohol 10\% (daun sirih + alkohol 10\%), pelarut alkohol 50\% (daun sirih + alkohol 50\%), pelarut alkohol 90\% (daun sirih + alkohol 90\%), pelarut etil asetat 10\% (daun sirih + etil asetat 10\%), pelarut etil asetat 50\% (daun sirih + etil asetat 50\%), pelarut etil asetat 90\% (daun sirih + etil asetat 90\%), pelarut n-heksana 10\% (daun sirih $+\mathrm{n}$-heksana 10\%), pelarut n-heksana 50\% (daun sirih $+\mathrm{n}$-heksana $50 \%$ ), dan pelarut n-heksana 90\% (daun sirih + n-heksana 90\%).

Pengujian Fraksi Ekstrak Daun Sirih dan Daun Babadotan. Pengujian C. capsici dilakukan pada media PDA dalam cawan petri. Masing-masing fraksi kering ekstrak daun sirih dan fraksi kering ekstrak daun babadotan dicampurkan dalam media PDA dengan konsentrasi $100 \mathrm{ppm}$. Selanjutnya biakan murni $C$. capsici diambil dengan bor gabus yang berukuran \pm 5 mm dan diletakkan pada tengah cawan petri yang berisi media PDA yang sudah diberi perlakuan ekstrak uji.

Pengamatan pertumbuhan jamur dilakukan dengan mengukur diameter koloni jamur dan pengamatan sporulasi jamur dilakukan dengan menghitung jumlah spora. Pengamatan terhadap diameter koloni jamur dilakukan pada hari ke-2 hingga hari ke-7 setelah infestasi. Pengukuran diameter koloni jamur dimaksudkan untuk mengetahui pertumbuhan dari jamur C. capsici sehingga kemampuan dari masing-masing fraksi skstrak daun sirih dan babadotan dalam menghambat pertumbuhan dan perkembangan $C$. capsici dapat diketahui. Pengamatan dilakukan dengan mengukur diameter terpanjang dan diameter terpendek dari masing-masing koloni. Kemudian dari kedua pengukuran tersebut dihitung diameter rata-rata koloni jamur C. capsici.

Jumlah spora dihitung dengan metode hitungan mikroskopis langsung menggunakan alat haemocytometer. Untuk menghitung kerapatan spora dilakukan dengan cara mengambil spora yang tumbuh pada setiap cawan petri dalam setiap ulangan. Kemudian dimasukkan ketabung reaksi ditambah $10 \mathrm{ml}$ aquades steril dan dihomogenkan. Selanjutnya meneteskan suspensi spora sebanyak 1 cc ke kaca objek dengan pipet tetes sehingga suspensi mengalir ke bawah kaca objek dan mengisi ruang hitung. Penghitungan jumlah spora dilakukan dalam kotak sedang yang masing-masing dilakukan dibawah mikroskop. Jumlah spora dihitung dengan mencari rata-rata jumlah spora dari lima kotak sampel yang di amati kemudian dibagi dengan volume dari setiap kotak sedang.

\section{HASIL DAN PEMBAHASAN}

Hasil Analisis ragam dan uji lanjut Duncan menunjukkan bahwa perlakuan tingkat fraksi pada ekstrak daun sirih memberikan pengaruh nyata terhadap diameter koloni $C$. capsici (Tabel 1). 
Tabel 1. Pengaruh fraksi ekstrak daun sirih terhadap diameter koloni Colletotrichum capsici pada pengamatan 2 hsi sampai 8 hsi.

\begin{tabular}{lccccccc}
\hline Perlakuan & \multicolumn{7}{c}{ Diameter koloni $(\mathrm{cm})$ pada daun sirih } \\
\cline { 2 - 7 } & $2 \mathrm{hsi}$ & $3 \mathrm{hsi}$ & $4 \mathrm{hsi}$ & $5 \mathrm{hsi}$ & $6 \mathrm{hsi}$ & $7 \mathrm{hsi}$ & $8 \mathrm{hsi}$ \\
\hline Kontrol & 0,50 & $1,37 \mathrm{c}$ & $1,77 \mathrm{c}$ & $2,40 \mathrm{c}$ & $2,84 \mathrm{c}$ & $3,10 \mathrm{~b}$ & $3,44 \mathrm{~b}$ \\
Daun sirih + aquades & 0,50 & $1,23 \mathrm{c}$ & $1,64 \mathrm{c}$ & $2,10 \mathrm{c}$ & $2,73 \mathrm{~b}$ & $3,08 \mathrm{~b}$ & $3,14 \mathrm{~b}$ \\
Daun sirih + alkohol 10\% & 0,50 & $0,75 \mathrm{a}$ & $1,08 \mathrm{a}$ & $1,75 \mathrm{~b}$ & $2,19 \mathrm{~b}$ & $2,69 \mathrm{~b}$ & $3,04 \mathrm{~b}$ \\
Daun sirih + alkohol 50\% & 0,50 & $0,85 \mathrm{~b}$ & $1,14 \mathrm{~b}$ & $1,64 \mathrm{a}$ & $2,28 \mathrm{~b}$ & $2,83 \mathrm{~b}$ & $3,02 \mathrm{~b}$ \\
Daun sirih + alkohol 90\% & 0,50 & $0,84 \mathrm{~b}$ & $1,64 \mathrm{c}$ & $1,95 \mathrm{~b}$ & $2,50 \mathrm{~b}$ & $2,94 \mathrm{~b}$ & $3,33 \mathrm{~b}$ \\
Daun sirih + etil asetat 10\% & 0,50 & $0,74 \mathrm{a}$ & $1,34 \mathrm{~b}$ & $1,67 \mathrm{~b}$ & $2,50 \mathrm{~b}$ & $2,84 \mathrm{~b}$ & $3,07 \mathrm{~b}$ \\
Daun sirih + etil asetat 50\% & 0,50 & $0,76 \mathrm{a}$ & $1,51 \mathrm{c}$ & $1,97 \mathrm{~b}$ & $2,19 \mathrm{~b}$ & $2,90 \mathrm{~b}$ & $3,11 \mathrm{~b}$ \\
Daun sirih + etil asetat 90\% & 0,50 & $0,73 \mathrm{a}$ & $1,31 \mathrm{~b}$ & $1,69 \mathrm{~b}$ & $2,04 \mathrm{a}$ & $2,42 \mathrm{a}$ & $2,76 \mathrm{a}$ \\
Daun sirih + n-heksana 10\% & 0,50 & $0,58 \mathrm{a}$ & $0,94 \mathrm{a}$ & $1,30 \mathrm{a}$ & $1,75 \mathrm{a}$ & $2,35 \mathrm{a}$ & $2,69 \mathrm{a}$ \\
Daun sirih + n-heksana 50\% & 0,50 & $0,57 \mathrm{a}$ & $0,81 \mathrm{a}$ & $1,25 \mathrm{a}$ & $1,49 \mathrm{a}$ & $1,98 \mathrm{a}$ & $2,39 \mathrm{a}$ \\
Daun sirih + n-heksana 90\% & 0,50 & $0,84 \mathrm{~b}$ & $1,08 \mathrm{a}$ & $1,45 \mathrm{a}$ & $1,52 \mathrm{a}$ & $2,10 \mathrm{a}$ & $2,57 \mathrm{a}$ \\
\hline F-hitung & 0,00 & $11,08^{*}$ & $11,67^{*}$ & $7,97^{*}$ & $6,74^{*}$ & $4,99^{*}$ & $5,25^{*}$ \\
\hline
\end{tabular}

Keterangan: Angka yang diikuti oleh huruf yang sama pada kolom yang sama tidak berbeda nyata berdasarkan uji Duncan pada $\alpha_{0,05}$. hsi = hari setelah investasi, Kontrol = media PDA tanpa perlakuan.

Tabel 1 menunjukkan bahwa ada empat perlakuan yang berpontesi sebagai biofungisida yaitu pada tingkat fraksi n-Heksana 50\%, n-Heksana 90\%, n-Heksana $10 \%$ dan Etil asetat $90 \%$. Keempat tingkat fraksi ini memberikan pengaruh ukuran diameter yang lebih kecil dari diameter koloni kontrol di setiap hari pengamatan setelah isolasi.

Dari berbagai fraksi ekstrak daun sirih, ada empat fraksi ekstrak n-Heksana 50\%, n-Heksana 90\%, nHeksana $10 \%$ dan Etil asetat $90 \%$ yang menunjukkan pengaruh penghambatan terhadap pertumbuhan $C$. capsici diduga terjadi karena kandungan minyak atsiri pada ekstrak tersebut. Menurut Sulistyani et al. (2007) dan Ajizah (2004), kandungan minyak atsiri yang terdapat dalam daun sirih diketahui mampu menghambat perkembangan jamur dengan cara mengganggu proses terbentuknya membran atau dinding sel. Nurhayati (2007) juga menjelaskan bahwa pada daun sirih, eugenol yang terkandung dalam minyak atsiri mampu mengakibatkan lysis pada miselium jamur sehingga dapat menghambat pertumbuhan dan bahkan mematikan jamur penyebab penyakit tanaman.

Hasil Analisis ragam dan uji lanjut Duncan menunjukkan bahwa perlakuan fraksi ekstrak daun sirih secara nyata menurunkan jumlah spora $C$. capsici pada media PDA. Jumlah spora $C$. capsici pada berbagai perlakuan disajikan pada Tabel 2. Jumlah spora $C$. capsici pada perlakuan fraksi aquades, alkohol (10\%, $50 \%, 90 \%)$ dan etil asetat $(10 \%, 50 \%)$ tidak berbeda dengan kontrol, sedangkan pada perlakuan etil asetat $90 \%$ dan n-heksana $(10 \%, 50 \%, 90 \%)$ berbeda nyata. Hal ini sejalan dengan hasil pengamatan terhadap pertumbuhan diameter koloni $C$. capsici. Menurut Guenther (1989), minyak atsiri mampu menghambat pertumbuhan sel vegetatif dan pertumbuhan spora jamur C. cereus, C. Subtilis, dan C. magaterium. Kandungan minyak atsiri yang terdapat dalam ekstrak daun sirih diduga mampu menghambat pertumbuhan vegetatif dan sporulasi jamur C. capsici.

Hasil Analisis ragam dan uji lanjut Duncan menunjukkan bahwa perlakuan fraksi pada ekstrak daun babadotan memberikan pengaruh nyata terhadap diameter koloni $C$. capsici dapat dilihat pada Tabel 3. Tabel 3 menunjukkan bahwa semua perlakuan fraksi ekstrak daun babadotan berpotensi sebagai biofungisida, kecuali aquades. Dari sembilan tingkat fraksi ekstrak yang secara nyata menghambat pertumbuhan koloni $C$. capsici tersebut, ada tiga tingkat fraksi ekstrak yang terbaik yaitu Heksana10\%, n-Heksana 50\% dan nHeksana 90\%. Ketiga tingkat fraksi ini menghambat pertumbuhan diameter koloni relatif lebih kecil di setiap hari pengamatan setelah isolasi.

Dengan demikian fraksi ekstrak babadotan yang berpotensi lebih tinggi sebagai biofungisida adalah $\mathrm{n}$ Heksana10\%, n-Heksana 50\% dan n-Heksana 90\%. Ekstrak daun babadotan pada tingkat fraksi n-Heksana $10 \%$, n-Heksana $50 \%$ dan n-Heksana $90 \%$ dapat berpengaruh menghambat pertumbuhan C.capsici diduga karena kandungan kimia dalam babadotan yang berupa minyak atsiri dan senyawa fenolik seperti saponin, flavanoid dan polifenol mampu berfungsi sebagai bio-fungisida (Ditjenbun, 1994).

Sebagian besar minyak atsiri termasuk kedalam golongan senyawa organik terpena dan triterpenoid yang 
Tabel 2. Jumlah spora Colletotrichum capsici pada berbagai perlakuan fraksi ekstrak daun sirih.

\begin{tabular}{lcc}
\hline Perlakuan & Jumlah Spora $\left(\mathrm{ml}^{-1}\right)$ & Notasi \\
\hline Kontrol & $4,7 \times 10^{5}$ & $\mathrm{~b}$ \\
Daun sirih + aquades & $4,0 \times 10^{5}$ & $\mathrm{~b}$ \\
Daun sirih + alkohol 10\% & $4,0 \times 10^{5}$ & $\mathrm{~b}$ \\
Daun sirih + alkohol 50\% & $4,2 \times 10^{5}$ & $\mathrm{~b}$ \\
Daun sirih + alkohol 90\% & $4,5 \times 10^{5}$ & $\mathrm{~b}$ \\
Daun sirih + etil asetat 10\% & $4,0 \times 10^{5}$ & $\mathrm{~b}$ \\
Daun sirih + etil asetat 50\% & $3,9 \times 10^{5}$ & $\mathrm{~b}$ \\
Daun sirih + etil asetat 90\% & $3,6 \times 10^{5}$ & $\mathrm{a}$ \\
Daun sirih + n-heksana 10\% & $2,7 \times 10^{5}$ & $\mathrm{a}$ \\
Daun sirih + n-heksana 50\% & $2,5 \times 10^{5}$ & $\mathrm{a}$ \\
Daun sirih + n-heksana 90\% & $3,3 \times 10^{5}$ & $\mathrm{a}$ \\
\hline F-hitung & $2,38^{*}$ & \\
\hline
\end{tabular}

Keterangan: Angka yang diikuti oleh huruf yang sama pada kolom yang sama tidak berbeda nyata berdasarkan uji Duncan pada $\alpha_{0,05}$. hsi = hari setelah investasi, Kontrol = media PDA tanpa perlakuan.

Tabel 3. Pengaruh fraksi ekstrak daun babadotan terhadap diameter koloni Colletotrichum capsici pada pengamatan 2 hsi sampai 8 hsi.

\begin{tabular}{lccccccc}
\hline Perlakuan & \multicolumn{7}{c}{ Diameter koloni $(\mathrm{cm})$ pada daun babadotan } \\
\cline { 2 - 8 } & $2 \mathrm{hsi}$ & $3 \mathrm{hsi}$ & $4 \mathrm{hsi}$ & $5 \mathrm{hsi}$ & $6 \mathrm{hsi}$ & $7 \mathrm{hsi}$ & $8 \mathrm{hsi}$ \\
\hline Kontrol & 0,50 & $0,95 \mathrm{c}$ & $1,61 \mathrm{c}$ & $2,00 \mathrm{c}$ & $2,43 \mathrm{c}$ & $2,88 \mathrm{c}$ & $3,25 \mathrm{c}$ \\
Daun babadotan + aquades & 0,50 & $0,89 \mathrm{c}$ & $1,52 \mathrm{c}$ & $1,87 \mathrm{c}$ & $2,18 \mathrm{c}$ & $2,57 \mathrm{c}$ & $3,99 \mathrm{c}$ \\
Daun babadotan + alkohol 10\% & 0,50 & $0,78 \mathrm{~b}$ & $1,03 \mathrm{~b}$ & $1,45 \mathrm{~b}$ & $2,89 \mathrm{~b}$ & $2,13 \mathrm{~b}$ & $3,32 \mathrm{~b}$ \\
Daun babadotan + alkohol 50\% & 0,50 & $0,75 \mathrm{~b}$ & $1,07 \mathrm{~b}$ & $1,39 \mathrm{~b}$ & $2,97 \mathrm{~b}$ & $2,16 \mathrm{~b}$ & $3,28 \mathrm{~b}$ \\
Daun babadotan + alkohol 90\% & 0,50 & $0,81 \mathrm{~b}$ & $1,25 \mathrm{~b}$ & $1,62 \mathrm{~b}$ & $2,09 \mathrm{~b}$ & $2,26 \mathrm{~b}$ & $3,43 \mathrm{~b}$ \\
Daun babadotan + etil asetat 10\% & 0,50 & $0,63 \mathrm{a}$ & $1,21 \mathrm{~b}$ & $1,45 \mathrm{~b}$ & $2,88 \mathrm{~b}$ & $2,00 \mathrm{~b}$ & $3,26 \mathrm{~b}$ \\
Daun babadotan + etil asetat 50\% & 0,50 & $0,66 \mathrm{a}$ & $1,11 \mathrm{~b}$ & $1,39 \mathrm{~b}$ & $2,65 \mathrm{~b}$ & $1,89 \mathrm{~b}$ & $3,02 \mathrm{~b}$ \\
Daun babadotan + etil asetat 90\% & 0,50 & $0,69 \mathrm{~b}$ & $1,29 \mathrm{~b}$ & $1,48 \mathrm{~b}$ & $2,70 \mathrm{~b}$ & $1,92 \mathrm{~b}$ & $2,11 \mathrm{~b}$ \\
Daun babadotan + n-heksana $10 \%$ & 0,50 & $0,54 \mathrm{a}$ & $0,69 \mathrm{a}$ & $0,78 \mathrm{a}$ & $1,86 \mathrm{a}$ & $0,97 \mathrm{a}$ & $2,02 \mathrm{a}$ \\
Daun babadotan + n-heksana $50 \%$ & 0,50 & $0,57 \mathrm{a}$ & $0,76 \mathrm{a}$ & $0,87 \mathrm{a}$ & $1,93 \mathrm{a}$ & $1,00 \mathrm{a}$ & $2,11 \mathrm{a}$ \\
Daun babadotan + n-heksana $90 \%$ & 0,50 & $0,69 \mathrm{~b}$ & $0,87 \mathrm{a}$ & $0,89 \mathrm{a}$ & $1,97 \mathrm{a}$ & $1,09 \mathrm{a}$ & $2,21 \mathrm{a}$ \\
\hline F-hitung & 0,00 & $9,88^{*}$ & $14,25^{*}$ & $20,30^{*}$ & $11,43^{*}$ & $25,21^{*}$ & $8,39^{*}$ \\
\hline
\end{tabular}

Keterangan: Angka yang diikuti oleh huruf yang sama pada kolom yang sama tidak berbeda nyata berdasarkan uji Duncan pada $\alpha_{0,05}$. hsi = hari setelah investasi, Kontrol = media PDA tanpa perlakuan.

bersifat larut dalam minyak merupakan senyawa nonpolar (Anonim, 2012). Minyak atsiri banyak tersusun oleh triterpenoid yang dihasilkan oleh daun babadotan. Senyawa triterpenoid yang ada dalam daun babadotan berfungsi mengganggu pertumbuhan sel jamur sehingga mengakibatkan kematian sel jamur (Zakiah, et al., 2003). Ekstrak daun babadotan fraksi n-heksana lebih banyak mengandung triterpenoid yang berperan sebagai fungisida (Gonzales, et al.,1991). Senyawa n-heksana adalah pelarut yang bersifat pelarut non-polar yang mampu melarutkan senyawa-senyawa non-polar seperti minyak atsiri. Semakin banyak kandungan bahan aktif minyak atsiri yang terdapat dalam suatu ekstrak maka semakin besar kemampuan minyak atsiri untuk menghambat pertumbuhan jamur C. capsici.
Hasil Analisis ragam dan uji lanjut Duncan menunjukkan bahwa perlakuan fraksi ekstrak daun babadotan memberikan pengaruh tidak nyata terhadap jumlah spora $C$. capsici pada media PDA. Jumlah spora pada berbagai perlakuan disajikan pada Tabel 4.

Berdasarkan pengamatan terhadap jumlah spora (Tabel 4), diketahui bahwa semua perlakuan fraksi ekstrak tidak berpengaruh nyata terhadap pertumbuhan spora $C$. capsici. Senyawa yang terkandung didalam ekstrak daun babadotan kemungkinan bersifat menghambat pertumbuhan vegetatif jamur (sprorulasi jamur) namun tidak mempengaruhi pertumbuhan generatif jamur. Seperti dijelaskan oleh Yuono (2012), kandungan senyawa antifungal dalam fungisida nabati sangat mempengaruhi kinerja fungisida tersebut dalam 
menghambat pertumbuhan jamur. Menurutnya, dalam jumlah yang sedikit senyawa antifungal hanya akan dapat mempengaruhi pertumbuhan vegetatif jamur seperti menghambat metabolisme, mengakumulasi globula lemak di dalam sitoplasma sel, mengurangi jumlah mitokondria, dan merusak membran nukleus pada jamur.

\section{KESIMPULAN}

Kesimpulan dari penelitian ini adalah Fraksi ekstrak daun sirih dan daun babadotan, mempunyai potensi sebagai fungisida nabati untuk mengendalikan C.capsici penyebab antraknosa buah cabai. Fraksi ekstrak daun sirih yang dapat menghambat pertumbuhan vegetatif jamur $C$. capsici dan jumlah spora $C$. capsici yaitu pada fraksi ekstrak n-Heksana 50\%, n-Heksana 90\%, n-Heksana 10\% dan Etil asetat 90\%. Fraksi ekstrak daun babadotan yang dapat menghambat pertumbuhan vegetatif jamur $C$. capsici yaitu fraksi ekstrak n-Heksana 10\%, n-Heksana 50\% dan nHeksana $90 \%$, tetapi ketiganya tidak berpengaruh terhadap jumlah spora.

\section{DAFTAR PUSTAKA}

Anonim. 2012. Minyak atsiri. Wikipedia.org/wiki. Diakses pada tanggal 14 Desember 2012.

Ajizah, A. 2004. Sensitivitas Salmonella typhimurium Terhadap Ekstrak Daun Psidium guajava L. Bioscientiae 1(1).

Ditjenbun. 1994. Pedoman Pengenalan Pestisida Botani. Direktorat Bina Perlindungan Tanaman Perkebunan, Ditjenbun, Deptan. Jakarta.

Gonzales, A.G., G. Thomas, dan P. Ram. 1991. Chromenes Form Ageratum conyzoides. Phytochemistry 30 .

Guenther, E. 1989. Minyak Atsiri. Universitas Indonesia. Jakarta.
Marjannah. 2004. Tumbuhan Babadotan sebagai Alternatif Insektisida Nabati. Visi Wacana 10(3).

Nazaruddin. 1999. Budidaya dan Pengaturan Panen Sayuran Dataran Rendah. Penebar Swadaya. Jakarta.

Nurhayati. 2007. Pertumbuhan Colletotrichum capsici penyebab antraknosa buah cabai pada berbagai media yang mengandung ekstrak tanaman. Jurnal Refflesia 9(1).

Octriana, L. dan Noflindawati. 2010. Pengaruh Air Panas dan Fungisida Nabati Terhadap Perkembangan Penyakit Pasca Panen pada Pepaya di Penyimpanan. Jurnal Teknologi Pertanian Andalas 15(2).

Semangun, H. 2000. Penyakit-penyakit Tanaman Hortikultura di Indonesia. Gadjah Mada University Press. Yogyakarta.

Sulistyani, N., Sasongko H., Hertanti M., dan Meilana L. 2007. Aktivitas Minyak Atsiri Daun Sirih Merah (Piper crocatum Ruiz and Pav) terhadap Staphylococcus aureus, Escherichia coli dan Candida albicans serta Identifikasi Komponen Kimianya. Med Far. 6(2).

Yuono, T. 2012. Kinerja Senyawa Antifugal Dalam Menghambat Pertumbuhan Patogen. http:// oxyge.wordpress.com. Diakses pada tanggal 15 Desember 2012.

Zakiah, Z., E. Marwani, Siregar, dan H. Arbayah. 2003. Peningkatan Produksi Azadirahtin dalam Kultur Suspensi Sel Azadirachta indica A. Juss melalui Penambahan Skualen. Jurnal Matematika dan Sains 8(4). 